\title{
Medidas de Segurança
}

\section{Basileu Garcia}

SUMARIO: 1 - Pena e medida de segurança. Os critérios teóricos de diferenciação. 2-O princípio da legalidade e a aplicação retroativa dos preceitos alusivos a medidas de segurança. 3 - A existência de uma infração penal é pressuposto da aplicação de medida de segurança. Exiceções à regra. 4- Indeterminação ıdo lapso de execução das medidas de segurança pessoais. 5 - A'valiação da periculosidade. A periculosidarde presumida. O problema da reincidência. Carater relativo da presunção legal. 6 Oportunidades da aplicação de medida de segurança. 7 - Sua execução. 8 - Flexibilidade do poder jurisdicional. 9 - Fuga e reinício da execução. 10 - Os tipos de medidas de segurança no direito brasileiro. 11 - Internação em manicômio judiciário. 12 - Internação em casa de custódia e tratamento. 13 - Internação em colônia agrícola, instituto de reeducação, de trabalho ou de ensino profissional. 14 - Liberdade vigiada. 15 - Exílio local e proibiçä̀o de frequentar determinados lugares. 16 - Interdição de estabelecimento ou sede de sociedade ou associação. 17 - Confisco. 18 - A expulsão de estrangeiro perante a medida de segurança. 19 - Medida de segurança e contravenção. 20 - Sintese das peculiaridades diferenciais entre a pena e a medida de segurança, deduzida dos nossios textos legislativos. Propostas doutrinárias tendentes à maior diversificação prática entre os dois institutos de reação social contra a criminalidade.

* 1. As medidas de segurança, sem dúvida o mais importante empreendimento do Código Penal de 1940, são,

* Do curso realizado na Faculdade de Direito de São Paulo. 
na ciência penal, tantas vezes secular, um instituto ainda muito novo. Conquanto hajam aparecido, na doutrina e nas aplicações práticas, já em fins do século passado, só de uns anos a esta parte vêm ganhando terreno e conquistando posição de realce nas legislações.

Elas constituem meios defensivos da sociedade. Visam preservar o ambiente social da ação nefasta do delinquente. Mas, pergunta-se: acaso a pena tambem não é medida de defesa?

Nas divergências que dividem os criminalistas acerca dos fins da pena, reuniu decisivas adesões a orientação de considerá-la como um meio de defesa da sociedade, preferentemente a manifestação de castigo. Através de tal concepção dos seus fins utilitários, a pena aproxima-se bastante da medida de segurança. $O_{S}$ escritores, todavia, têm envidado estabelecer separação entre as duas espécies de providências, atribuindo, a cada uma das formas de reação contra o delito, traços característicos próprios.

Há certa dose de artificialismo nessa tarefa, enquanto paira no plano doutrinário. Mas na concretização dos textos legislativos os dois institutos se vão distanciando, através das peculiaridades de organização que lhes são prefixadas.

Antes de penetrar no exame dos preceitos legais, para mostrar em que consistem, especialmente na legislação criminal brasileira, as distinções a assinalar, procuremos indicar os aspectos diferenciais que têm sido preconizados no campo doutrinário.

Tem-se dito que a pena continua a ser um castigo, ainda que, cada vez mais, se pretenda expungi-la do carater retributivo e expiatório. Embora se intente, na sua execução, evitar afligir o condenado, causar-lhe um sofrimento que o faça recebê-la como punição, na verdade a pena jamais perderá, $\mathrm{n}_{0}$ consenso geral, a eiva de paga do mal pelo mal, malum passionis quod infligitur ab malum actionis. Ora, em contraposição, as medidas de segurança não traduzem 
castigo. Foram instituidas ao influxo do pensamento da defesa social, atendendo à preocupação de prestar ao delinquente uma assistência rehabilitadora.

À pena - acrescenta-se - invariavelmente se relaciona um sentimento de reprovação social, mesmo porque se destina a punir, ao passo que às medidas de segurança não se volta a pública animadversão, exatamente porque não representam senão meios assistenciais e de cura do indivíduo perigoso, para que possa readaptar-se à coletividade.

As penas são proporcionadas à gravidade do delito. Quer na sua fase cominatória, nos textos abstratos da lei, quer na sua fase de aplicação pelo juiz, existe relativa proporcionalidade entre a maior ou menor potencialidade lesiva da infração e a respectiva pena. Ao revés, no que concerne às medidas de segurança, não há indeclinavel relação entre o delito e a maior ou menor intensidade de tais medidas, que, sob a influência de um critério estritamente subjetivista, se proporcionam tão só à periculosidade do criminoso. Este pode ser um indivíduo deveras temivel e ter praticado uma infração insignificante. Nem por isso estará livre de medida de segurança das mais rigorosas, com restrição a um dos seus mais valiosos bens jurídicos, particularmente a liberdade.

Advirta-se, a esse respeito, que existe harmonia entre a externação prática das penas e a das medidas de segurança. Tanto aquelas como estas se endereçam às mesmas espécies de bens jurídicos. Quando se impõe uma pena, ofende-se o delinquente em sua liberdade ou em seu patrimônio (em nossa legislação penal comum, não se cogita de ofensa ao direito à vida, visto que não possuimos, senão na legislação especial, a pena de morte). O mesmo acontece com a medida de segurança, que se consubstancia em restrições à liberdade ou ao patrimônio.

Assim temos sumariado alguns dos pretendidos sinais distintivos. E acabamos, tambem, de estabelecer a aproximação inegavel entre umas e outras providências, através. 
de um aspecto importante: a identidade de natureza dos bens jurídicos a que se endereçam as duas modalidades de combate ao delito.

Em verdade, a diferenciação não é muito convincente. Acaso a medida de segurança deixará de ser recebida, por quem a cumpre, como uma punição? Não importa proclamar-se que a medida de segurança não castiga, quando é certo que ao impô-la se obriga, por exemplo, um homem a privar-se da liberdade, por anos a fio. Com a expressiva circunstância, ainda, de que um dos característicos jurídicos da medida de segurança é a sua indeterminação, que não tem sido admitida pela generalidade das legislações em relação às penas.

Os anátemas da conciência social que, segundo se imagina, acompanham a pena, pouparão, porventura, o individuo submetïdo a medida de segurança? Ainda é discutivel(1). Afinal, o que logicamente se deve esperar que a censura pública alcance é o críme, não determinadas espécies dentre os métodos de guerreá-lo. Se o crime é antecedente obrigatório da pena, tambem o é, quasi sempre, da medida de segurança. E será possivel apreciar a intensidade, o valor e mesmo a positiva existência de algo abstrato, como é o suposto estigma emanado do entendimento popular?

O esteio menos inseguro da distinção parece que se reduz a que é exclusivamente a periculosidade do criminoso que decide da aplicação das medidas de segurança, enquanto na da pena se tem em vista o crime em sí mesmo, em seus

(1) P. Cornil, com a sua experiência de diretor da Prisão escola de Hoogstraeten, opina que, seja a providência defensiva da sociedade executada em um cárcere, propriamente dito, ou em um estabelecimento de educação ou em uma colônia para vagabundos ou reincidentes, é sempre o mesmo o estigma de reprovação que atingirá o indivíduo, no consenso geral. o liberado, conclue, qualquer que seja a natureza do instituto de que saiu, é sempre considerado como um egresso da prisão Alcune considerazioni sugli effeti dell'internamento dei delinquenti, na Rivista di Diritto Penitenziario, 1935, p. 78"). 
dois elementos, objetivo e psíquico: a materialidade do fato e a culpabilidade.

$\mathrm{O}_{\mathrm{S}}$ mais denodados defensores da diferenciação colocam o aspecto psíquico à luz do princípio da periculosidade, frisando que a pena, por isso que reclama imputabilidade e voluntariedade, é inconfundivel com a medida de seguranç, que as dispensa. Assim, Battaglini. Nítida, declara, é a diferença: "quando nos encontramos perante alguem que é simplesmente perigoso, o senso comum exprime um juizo de valor totalmente diverso do que manifesta em face de um indivíduo culpado. $\mathrm{O}$ direito não pode desatender a esse dado da realidade" (2).

Mas ainda através desse prisma objeções são suscitaveis. $O$ direito penal contemporâneo leva muito em conta, para a aplicação da pena, a periculosidade. Certas circunstâncias, consideradas pela lei como agravantes, têm a sua razão de ser na evidente revelação de perigo social do agente contra o qual militam. A tarefa judicial de fixação da pena é, em grande parte, um trabalho de apreciação da periculosidade, como, no direito brasileiro, promana do art. 42 do Código Penal.

De outra parte, veremos, no estudo dos textos legais, que as medidas de segurança conservam certa correlação com a variavel gravidade dos crimes. Nem seria possivel banir todo paralelismo, porquanto a maneira de ser do delito e o modo de praticá-lo o delinquente contribuem para aferir-se a periculosidade, da qual a conduta criminosa é o mais significativo sintoma.

A substancial identidade entre penas e medidas de segurança, escreve SAbatini (3), foi reconhecida quando os maiores criminalistas, repelindo as velhas doutrinas místicas e expiacionistas, atribuiram à pena, como sua função basi-

(2) G. Battaglini, Diritto Penale - Teorie Generali, Bolonha, 1937, p. 378.

p. 525 .

(3) G. Sabatini, Istituzioni di Diritto Penale, 1.० vol., 1935, 
lar, um escopo preventivo. Não existe, diz, entre as penas e as medidas de seguranca, ontologicamente, nenhuma diferença de conteúdo, nem uma clara e precisa linha demarcatória. Entrelaçam-se os objetivos e efeitos de umas e outras. A pena, a um só tempo, é meio de repressão e prevenção (4), porquanto, reprimindo e ameaçando, previne a realização de novos delitos pelo culpado e pelos destinatários da norma penal, em geral. A seu turno, a medida de segurança, preventiva porque anula ou atenua, as causas individuais de novos delitos, não deixa de constituir meio repressivo, quando, no intuito de modificar a personalidade do delinquente, se materializa numa limitação, maior ou menor, de direitos referentes à liberdade ou ao patrimônio.

A despeito da diminuta valia dos critérios teóricos de diferenciação, o empirismo legislativo outorga às medidas de segurança uma regulamentação especial, que reclama a nossa atenção. Nela se entrevêem derrogações e limitações. das normas instituidas para as penas.

2. Importante, sob tal aspecto, é o art. 75 do Código Penal, que diz o seguinte: "As medidas de segurança regem-se pela lei vigente ao tempo da sentença, prevalecendo, entretanto, se diversa, a lei vigente ao tempo da execução". Esse texto lembra-nos o princípio da legalidade dos delitos e das penas. Relativamente aos delitos, não é possivel a aplicação de pena que não conste expressamente de um texto anterior à prática da infração. Aplica-se, sem restrições, à repressão dos crimes, a máxima: nullum crimen nulla poena sine lege. Esse principio não vigora, inteiramente, para as medidas de segurança. Decorre do art. 75 não seŕ possivel a aplicação de medida de segurança sem lei anterior que a regule. As medidas de segurança não

(4) Asúa (La Unificación del Derecho Penal en Suiza, Madri, 1916, p. 234) recorda, a propósito, a frase de LiszT: "O tempo da estrita separação entre prevenir e reprimir já passou, e não nos devemos admirar de ver figurarem em um Código Penal medidas de simples segurança". 
podem ser impostas disçricionariamente. São estritamente legais. É preciso que uma lei as estabeleça, que um preceito as defina, para que possam ser utilizadas. Não é, porem, indispensavel que o texto referente às medidas de segurança anteceda a prática do crime: basta que anteceda a execução da medida de segurança.

Insofismavel, portanto, é a retroatividade dos preceitos alusivos a medidas de segurança, em relação ao fato criminoso denunciador de periculosidade. $\mathrm{E}$ mais se acentua a sua força retroativa considerando-se que o advento de uma lei modificadora, já ao tempo da execução da medida, influirá sobre o seu regime.

A razão está em que as medidas de segurança têm em alvo a periculosidade do delinquente, que está presente. integral, no momento em que vai ser imposta a medida em virtude de lei. Ao passo que as penas são fundamentalmente proporcionais à gravidade do crime, que é definido pela lei e cuja importância na seriação, na escala das infrações, resulta de preceitos penais prévios. As penas encaram o passado. As medidas de segurança voltam-se para o futuro. As penas alicerçam-se no fato de autoria e responsabilidade do delinquente, fato já consumado. As medidas de segurança têm em mira os males que ele poderá perpetrar, os delitos a decorrerem do seu estado perigoso, que necessita ser obviado.

Com essa justificação poder-se-ia mesmo ser induzido a afirmar, teoricamente, que o instituto que estudamos não infringe o principio da irretroatividade das normas penais. Se as medidas de segurança agem em função de uma potencialidade perigosa a exteriorizar-se, dir-se-á, não regem o passado. A justificação seria completa se não fosse pressuposto do emprego de qualcuer dessas medidas a pretérita ocorrência de uma infração à lei penal.

3. A periculosidade de um individuo pode ser revelada por um crime e, tambem, por um comportamento não criminoso. Receou, todavia, o legislador, ampliar excessiva- 
mente a órbita do novo instituto e, a exemplo de outros estatutos, dispôs que, em princípio, só se aplicará medida de segurança a pessoa que tenha cometido infração à lei penal. Abrem-se duas exceções: aplica-se a medida chamada liberdade vigiada ao autor de tentativa absolutamente impossivel e nos casos de ajuste, determinação ou instigação e auxílio para crime que não chega a ser tentado. É condição seja perigoso o acusado, condição, aliás, sempre de considerar-se em matéria de medida de segurança (art. 76 e parágrafo único do Código Penal).

4. Da premissa de que as medidas de segurança objetivam combater a periculosidade, deriva uma consequência digna de ser destacada. Elas seriam inaptas ao mister a que se dirigem se fossem predeterminadas na sua execução, isto é, se estivessem sujeitas a prazos fatais. Nunca se pode dizer qual é o tempo indispensavel para reduzir-se à inocuidade um delinquente perigoso. Eis porque, ao passo que em relação às penas se conserva o sistema de determinação, não podendo as privativas de liberdade exceder o limite a que é condenado o infrator, no que respeita às mais importantes medidas de segurança é um característico do seu sistema a indeterminação, como corolário da assertiva de que elas visam coartar a periculosidade.

Exprime-o o art. 81 do Código Penal: "Não se revoga a medida de segurança pessoal, enquanto não se verifica, mediante exame do individuo, que este deixou de ser perigoso. $\S 10^{\circ}$ - Procede-se ao exame: I - ao fim do prazo mínimo fixado pela lei para a medida de segurança; II anualmente, após a expiração do prazo mínimó, quando não cessou a execução da medida de segurança; III - em qualquer tempo, desde que o determine a superior instância. $\S 2 .^{\circ}$ - Se inferior a um ano o prazo mínimo de duração da medida de segurança, os exames sucessivos realizam-se ao fim de cada periodo igual àquele prazo". 
Apreende-se desse texto que as medidas de segurança pessoais não poderão ser revogadas enquanto não cessar a causa que as originou, enquanto não se comprovar o desaparecimento do perigo social, encarnado no delinquente. A lei aponta, então, prazos para a verificação da periculosidade, para se saber se já se extinguiu. De tempos a tempos faz-se um exame: o primeiro é realizado na época em que deveria terminar, normalmentę, a medida de segurança. Porque o juiz, quando a impõe, lhe estabelece um tempo de duração mínimo. Se o exame der resultado contrário ao paciente, deverá ser renovado ao fim de mais um ano ou, se tiver a medida sido imposta por lapso inferior a um ano, ao fim do prazo de duração, e assim sucessivamente, repetindo-se anualmente, na primeira hipótese, e a intervalos iguais ao tempo de duração da medida, na segunda hipótese, até que se chegue, se possivel, a conclusão favoravel.

Esse sistema, entretanto, seria capaz de por em sério risco o direito à liberdade individual. Poderia dar-se que determinado autor de crime não fosse realmente perigoso, que se verificasse plenamente a ausência da sua periculosidade, apesar de que não houvesse chegado ao término do prazo mínimo estabelecido na lei. E, então, o legislador cautelosamente incluiu uma válvula para evitar demasias: permitiu que o Tribunal de Apelação, a requerimento, quer do acusado ou de pessoas que o representem, quer do próprio Ministério Público, ordene, fora das épocas normais, a realização de exames relativos à periculosidade (5).

(5) A despeito da sua geral similitude com a legislação italiana, a nossa disciplina legal das medidas de segurança oferece, relativamente àquele modelo, e com inegavel vantagem, uma diferença de vulto. Ao contrário do que acontece no direito brasileiro, no Código Rocco a duração mínima da medida de segurança pessoal não é susceptivel de ser obstada por determinação de Tribunal superior. "A revogação", diz o art. 207 daquele diploma, "não pode ser ordenada enquanto não decorrer o tempo correspondente à duração mínima estabelecida pela lei para cada medida de segurança". A revogação pode, porem, dar-se anteis de findar-se o prazo mínimo, mediante decreto do ministro da Justiça. Mas a natureza excepcional de um tal decreto permite assegurar que no direito italiano, 
O Código de Processo Penal regula com minúcias a verificação da persistência ou desaparecimento da periculosìdade (arts. 775 a 778 ).

Em meio às diferenças empiricamente firmadas na lei entre as penas e as medidas de segurança, sobressai, como indubitavelmente a mais notavel, essa, proveniente da duração indeterminada de tais medidas. Não possuimos penas perpétuas. Uma disposição constitucional proibe-as peremptoriamente. Entretanto, as medidas de segurança pessoais, condicionada a sua cessação ao desaparecimento da periculosidade, podem tornar-se, iniludivelmente, perpétuas.

Sem o carater indeterminado da sua duração, as međidas de segurança seriam inaptas para a sua função essencial: anular a periculosidade. Limitá-las irremediavelmente no tempo equivaleria a tolhê-las, em inúmeros casos, de atingir a sua finalidade. Representaria isso uma incongruência. E então seria melhor que ficássemos só com o instituto das penas, sem a inovação.

A escola positiva era infensa a distinções entre os meios de defesa social. Constituiam todos, simplesmente, sanções (6). Nesse sentido dispunha o projeto FERri, de 1921.

conquanto indeterminadas em seu máximo, as medidas de segurança pessoais são determinadas em seu minimo. No direito brasileiro, o facil recurso ao Tribunal de Apelação comunica tambem ao limite minimo o carater de indeterminação.

A "Relazione Ministeriale al Proggetto Definitivo" procura justificar o sistema do mínimo irrevogavel nas medidas de segurança. DE MARSIco contradita a argumentacão, vislumbrando no mecanismo adotado a intercorrência de principios que só têm cabimento para as penas (II Codice Penale Illustrato Articolo per Articolo, direção de Ugo Contr, 1.० vol., Milão, 1934, p. 891).

(6) No Congresso Internacional de Direito Penal de Bruxelas (1926), os penalistas argentinos Jorge E. Coll e JuAN P. Ramos, partidários da unificação das providências anti-criminais, opinaram que nenhuma palavra seria melhor do que a do projeto FerRI, sanções, para designar, nos Códigos do futuro, simultaneamente, a pena, conforme ao conceito clássico, e a medida de segurança, do conceito experimental moderno. Já o mestre francês JEAN-ANDRé Roux, defensor da tese dicotômica, enquanto acolhia o movimento de progresso em favor das medidas de segurança, pugnava pela conservação da idéia de responsabilidade moral e de pena, que é a sua conse- 
O dualismo, que veio a predominar nas legislações, - penas e medidas de segurança - exorbita ao seu sistema. A dificuldade de sustentar a diferenciação ontológica poderia ter conduzido o legislador brasileiro a uma disciplina unitária da matéria, se não fosse o empecilho trazido pela proibição constitucional de indeterminação das penas, a qual conduz à sua eventual perpetuidade (7). O óbice foi, como se vê, jeitosamente arredado, chamando-se "medida de segurança" à segregação perpétua...

\section{Como se aprecia a periculosidade?}

Nela se deve identificar, não a mera possibilidade, mas a probabilidade de que o individuo tornará a delinquir (8).

o Código Penal não poderia desamparar o juiz de critérios para avaliá-la, no desempenho de uma função psicológica extremamente delicada.

Em certos casos, o legislador presume a periculosidade. como consectário de determinados fatos, taxativamente mencionados. Em outros casos, confia o exame ao juiz. $\mathrm{Na}$ verificação da periculosidade não presumida, deverá o juiz atender ao disposto no art. 77 do Código Penal, observando a personalidade do imputado, investigando os seus

quência, como elemento de disciplina e ordem na sociedade ( $J u$ risprudência Argentina, vol. 25. ${ }^{\circ}, 1927$, ps. 43 e segs., secção doutrinária, sobre o Congresso Internacional de Direito Penal).

(7) Um dos autores do nosso Código, Roberto Lyra, a quem se afigura de invencivel artifícío a distinção entre pena e medida de segurança, reconhece que o novo estatuto a acolheu para contornar o preceito do art. 122 , n. ${ }^{\circ} 13$, da Constituição de 1937, proibitivo da perpetuidade das penas (Comentários ao Código de Processo Penal, edição da Rev. Forense, 6.0 vol., Rio, 1944, p. 400).

(8) Tornará a delinquir é expressão que emprego partindo da regra geral da necessidade de um fato objetivamente criminoso como antecedente da aplicação de medida de segurança, regra que comporta, em nosso direito, as duas exceções já indicadas (n.० 3).

Cogitando, porem, de tais exceções, o art. 77 fala na suposição de que o delinquente venha ou torne a delinquir: "Quando a periculosidade", preceitua esse dispositivo, "não é presumida por lei, deve ser reconlhecido perigoso o individuo, se a sua personalidade e antecedentes, bem como os motivos e circunstâncias do crime, autorizam a suposição de que venha ou torne a delinquir". 
antecedentes, os motivos e as circunstâncias da sua conduta, afim de lhe apurar possivel capacidade criminógena.

A idéia de periculosidade, a presidir a administração dos processos de combate à delinquência, é a mais incontestavel realização legada pela escola positiva ao direito objetivo. Em seus primórdios, o conceito foi expresso por diferente palavra - temibilidade, que Garofalo definia como a perversidade constante e ativa do criminoso e a quantidade de mal previsto, que dele caberia esperar (9).

"Presumem-se perigosos", diz o art. 78, "aqueles que, nos termos do art. 22, são isentos de pena". Os isentos de pena em virtude do art. 22 são os indivíduos absolvidos pela dirimente da inimputabilidade absoluta — os enfermos ou deficientes mentais sem discernimento. São aqueles que, ao tempo da ação ou da omissão, eram inteiramente incapazes de entender o carater criminoso do fato ou de determinarse de acordo com o seu entendimento, em consequência de doença mental ou desenvolvimento mental incompleto. Em segundo lugar, presumem-se perigosos os individuos "referidos no parágrafo único do art. 22": são os delinquentes de imputabilidade restrita, ou fronteiriços, os semi-loucos, os "demi-fous", de que falava Grasset. Em terceiro lugar, "os condenados por crime cometido em estado de embriaguez pelo alcool ou substância de efeitos análogos, se habitual a embriaguez". Em quarto lugar, "os reincidentes em crime

(9) Incontestavel è a vantagem da expressão periculosidade (ou periculosidade social, como diz, mais extensamente, o Código italiano, art. 203), sobre o vocábulo temibilidade. $\mathrm{O}$ individuo será temivel por ser perigoso. A sua temibilidade, fenómeno de projeção ambiental, é decorrência do seu pessoal estado perigoso.

Todavia, é curiosa a argumentação de MANzini ao assinalar a sua preferência. Aferrado aos preconceitos do classicismo penal, ele jamais tolera sem restrições as vitórias da corrente adversa. "A lei", expôs o ilustre penalista do defunto fascismo, "a lei acolheu com justeza a critério da periculosidade social, e não o da temibilidade, adotado por alguns positivistas. Temer uma pessoa é sentimento de pusilanimidade (viltà) ou fraqueza, que, se é próprio de individuos medrosos, não se pode conceber no Estado, e muito menos no Estado fascista" (Istituzioni di Diritto Penale Italiano, Pádua, 1935, p. 253). 
doloso"; e, em quinto lugar, "os condenados por crime que hajam cometido como filiados a associação, bando ou quadrilha de malfeitores". Em qualquer dessas hipóteses dispensa-se ao magistrado o trabalho de verificação da periculosidade. Est'a existe, reconhecida pela lei.

Por aí vemos que as medidas de segurança - e eis um dos seus aspectos importantes no terreno das disposições legais - tanto se podem aplicar a delinquentes condenados como a delinquentes absolvidos. Os indivíduos ä que alude o art. 22, isto é, os enfermos mentais inimputaveis, são absolvidos, o que não impede fiquem submetidos a medidas de segurança.

Note-se a referência aos reincidentes em crimes dolosos. Foi mesmo o problema da reincidência um dos que em maior notoriedade colocaram a matéria das medidas de segurança, na doutrina e na prática criminais. As legislações nos moldes clássicos eram impotentes para refrear a reincidência. Tornavam à conduta anti-social, inúmeras vezes, delinquentes já punidos, numa desanimadora demonstração do fracasso das penas, como processo reeducativo e regenerador. $\mathrm{Pa}$ recia que novos métodos de combate a esses indivíduos deviam ser escogitados. Surgiram as medidas de segurança $e$, com elas, a esperança de solução do desconcertante problema da recaida no crime (10).

A fixidez da duração das penas fazia com que o reincidente recobrasse a liberdade ainda que não estivesse em condições de voltar, sem perigo, ao convivio social. Atualmente, no direito brasileiro, o reincidente em crime doloso está sujeito a ficar segregado da sociedade por tempo ilimitado, ainda que lhe seja imposta uma breve pena de prisão, e isso

(10) Comenta Logoz que na Suiça o dispositivo legal que instituiu a segregação, por tempo indeterminado, dos delinquentes habituais, como medida de segurança, foi recebido como um dos maiores progressos alcançados naquele país pelo direito penal (PAUL Logoz, Commentaire du Code Pénal Suisse, parte geral, 1939, p. 190). 
em consequência do carater indeterminado do tempo de execução da medida de segurança cabivel.

A presunção de periculosidade cede, em certos casos, a prova em contrário. E' o que se exprime nos parágrafos $10^{\circ}$ e 2. ${ }^{\circ}$ do artigo 78. Pode dar-se que se delibere acerca da aplicação de medida de segurança a indivíduo presumidamente perigoso muito tempo depois do fato delituoso. E' possivel que tenha cessado, na verdade, a periculosidade que a lei presumiu existir.

Por circunstâncias especiais, como, por exemplo, a tardia descoberta do acontecimento criminoso ou a fuga do acusado, o processo chega à fase de sentença vários anos depois da prática da infração. Com atinência ao estabelecido no $\S 10^{\circ}$ citado, deixar-se-á de levar em conta a presunção. Ainda: como a execução das medidas de segurança é posterior à das penas, deve ser feita efetiva verificação da periculosidade antes de iniciar-se a execução das mencionadas medidas, quando houverem decorrido os lapsos de tempo a que alude o $\S 20^{\circ}$ (11). Ressalva-se, nesse parágrafo, o disposto no art. 87, e tal restrição significa, principalmente, que, passados cinco anos da data em que o sentenciado terminou o cumprimento da pena, se não tiver sido iniciada a execução da medida de segurança que acaso lhe haja sido imposta, não poderá mais ser executada, desde que ele não tenha voltado a delinquir durante aqueles cinco anos. Considera-se a regularidade da sua conduta em

(11) A contingência de se averiguar se perdura a periculosidade antes do início da execução da medida de segurança é mais comum do que o faz supor 0 art. $78, \S 2 .^{\circ}$, do Código Penal. O livramento condicional pode ser concedido a sentenciados que, por serem considerados perigosos na ocasião do veredictum condenatório, ficam sujeitos a medida de segurança, a executar-se depois de cumprida a pena. A concessão do favor legal depende de ausência ou cessação da periculosidade (art. 60, n. II). O beneficiário isentase, mesmo, da medida de segurança (art. 66). Assim, ainda antes dos prazos de dez a cinco anos a que alude o art. 78 , $\$ 2 .^{\circ}$, ter-se-á de verificar se continua perigoso o recluso ou detento que esteja para ingressar no derradeiro estágio da pena, o de liberdade condicional. 
todo esse lapso de tempo como prova de que cessou a sua periculosidade.

A sentença estrangeira, quando a aplicação da lei brasileira produz na espécie as mesmas consequências, pode ser homologada no Brasil para sujeitar o condenado a medidas de segurança pessoais, diz o art. $7 .^{\circ}$ do nosso Código. Mas a presunção de periculosidade, decorrente acaso do fato, não será admitida. $O \S 3 .^{\circ}$ do art. 78 manda que se verifique a periculosidade.

6. Em que ocasião deve ser aplicada medida de segurança? O artigo 79 do Código Penal regula a matéria, que é tambem subsidiariamente prevista em diversos preceitos do Código de Processo Penal (arts. 751 e seguintes.) Verifica-se, de uma apreciação sistemática acerca de tal ponto, que a medida de segurança pode ser aplicada pelo julgador antes da sentença que vai proferir na causa, no momento da sentença e depois dela.

Antes da sentença, poderá aplicar medida de segurança em carater provisório, nos termos do artigo 80 do Código Penal, aos irresponsaveis por enfermidade ou deficiência mental e a ébrios habituais ou toxicómanos, que tenham delinquido em consequência dessas suas condições anômalas. Esclarece o parágrafo único que na duração definitiva da medida de segurança será computado o tempo da aplicação provisória.

A providência é análoga à prisão preventiva, que constitue verdadeira antecipação da pena privativa de liberdade, em cuja espectativa é decretada, nos casos, previstos no Código de Processo Penal, em que tão grave restrição é reclamada pelo interesse da Justiça.

No ato da sentença o juiz pode impor medida de segurança. Sentença de condenação ou de absolvição? Parece, à primeira vista, que será em sentença de condenação, pois que é pressuposto da imposição de medida de segurança a existência de um crime, e a absolvição implica em afirmar que o crime não foi praticado, ou não existe, ou, enfim, 
dele o acusado não é responsavel. Alem disso, a sentença de absolvição importa, quasi sempre, no reconhecimento de que o indivíduo não é perigoso. A verdade, entretanto, resultante dos textos e consentânea com o interesse social, é que tanto se pode aplicar medida de segurança em sentença condenatória como em sentença absolutória. Não permite dúvida o art. 79: "A medida de segurança é imposta na sentença de condenação ou de absolvição". Os individuos absolutamente inimputaveis, de que trata o artigo 22 do Código Penal, que os declara livres de pena, estão sujeitos a medida de segurança, a ser-lhes aplicada na sentença de absolvição. Determinado réu é absolvido porque praticou um crime em estado de loucura. Seria uma temeridade restituí-lo, sem mais considerações, ao ambiente social. 0 juiz ordena a sua internação em manicômio judiciário, isto é, aplica-lhe, na sentença absolutória, medida de segurança.

A decisão que exime de pena pode ter por fundamento uma das causas de extinção da punibilidade catalogadas no art. 108 do Código Penal. Não será, então, aplicavel medida de segurança (art. 86). A leitura dos incisos em que aquelas causas são indicadas convence de que raro alguma delas coexistirá com manifestação de periculosidade do réu.

Acresce que, no sistema da nossa lei, a medida de segurança, em princípio, pressupõe, com a existência do crime, a sua punibilidade. E', em regra, um complemento da pena (12).

Mesmo depois de imposta uma pena, pode adicionar-se a ela, por decisão do magistrado criminal, medida de segurança. Isso em casos que são especificados nos dois referidos estatutos. Sem analisá-los pormenorizadamente, mostro, porem, a título de exemplo, através de um dos textos (art. 751, n. ${ }^{\circ}$ II, do Código de Processo), o largo poder que se outorga ao juiz nesse assunto: "Durante a execução da pe-

(12) Entretanto, o Código italiano admitiu em certos casos a aplicação de medidas de segurança a despeito da extinção da punibilidade (art. 210). 
na ou durante o tempo em que a ela se furtar o condenado, poderá ser imposta medida de segurança, se: ... II - tendo sido, expressamente, excluida na sentença a periculosidade do condenado, novos fatos demonstrarem ser ele perigoso". Pode dar-se, portanto, que o juiz, na sentença condenatória, conclua que o delinquente não é perigoso. Deve ser condenado porque praticou um crime e não tem a seu favor escusa alguma, mas não parece provavel que volte a delinquir. Isenta-o, assim, de forma expressa, da aplicação de medida de segurança. Mais tarde, novas circunstâncias vêm demonstrar a sua periculosidade, obrigando o juiz a impor medida de segurança. E o Código de Processo elucida em que situações deverá ter lugar a imposição, quais as verificações a serem feitas. Cabe ao diretor do estabelecimento presidiário em que está cumprindo pena o delinquente dar, ao magistrado, informações que o habilitem a apreciar a existência da periculosidade primitivamente excluida.

Se, como se nota, é possivel aplicação ulterior de medida de segurança, mesmo que a sentença exclua a periculosidade, com mais razão se dará em outras hipóteses, em que a sentença apenas seja omissa acerca desse ponto. $\mathrm{E}$, com efeito, a lei o permite, em variados casos que constam dos arts. 751' e 752 do Código de Processo Penal, os quais desenvolvem e ampliam o texto, já longo, do art. 79 do Código Penal. Permite-o não só após passar em julgado a sentença condenatória, como tambem, num caso, após o trânsito em julgado de sentença absolutória: a aplicação de medida de segurança é possivel, enquanto não decorrido o tempo equivalente ao da sua duração mínima, a indivíduo que a lei presuma perigoso (art. 79, n. ${ }^{\circ}$ II, do Código Penal; art. 753 do Código de Processo Penal). Essa permissão é utilizavel relativamente ao criminoso louco absolvido que o juiz, ao sentenciar, tenha deixado de mandar internar no Manicômio Judiciário. 
7. Deve a medida de segurança executar-se antes da pena ou depois dela? Os escritores discutem a questão, opinando uns que, sendo providência de cura, de assistência, deverá ser aplicada antes da pena. Outros se manifestam em sentido contrário.

O problema aparece principalmente a propósito da me. dida de segurança aplicavel a indivíduos evidentemente anormais, mas responsaveis, como os que ficam sujeitos a internação em casa de custódia e tratamento (13)

No mecanismo adotado pelo nosso Código, o sentenciado cumpre, em primeiro lugar, a pena privativa de liberdade e, depois, a medida de segurança. Se se tratar de sentença absolutória, ou de condenação a multa exclusivamente, o início da execução tão só aguarda passe em julgado a sentença.

8. Providências de cunho administrativo, embora jurisdicionalmente impostas e fiscalizadas, a lei confere certa elasticidade às medidas de segurança, o que permite, em determinados casos, a substituição de umas por outras, mesmo em plena fase executória. E' o que, por exemplo, se depara no art. 83 do Código Penal, que acode à conveniência de substituir-se medida de segurança detentiva pelo recolhimento a manicômio judiciário, ou, à falta, a estabelecimento adequado, quando sobrevem ao paciente doença mental.

As restantes preceituações do extenso dispositivo continuam atribuindo ao magistrado poderes para, após a cura do enfermo, lhe proporcionar o regime preventivo que con-

(13) Reportando-se a Altavilla (Lineamenti di Diritto Criminale, Nápoles, 1932, p. 341), Ataliba Nogueira desdobra em três grupos os sistemas propostos acerca do assunto: a) a medida de segurança precede à pena; b) a pena precede à medida; c) a pena deve desaparecer, absorvida na medida de seguranca. Esta última é a teoria positivista, que visa arredar o seguinte dilema: "infligir pena a quem não é perfeitamente normal é uma crueldade; fazer a pena esperar a cura significa punir um homem diferente daquele que cometeu o delito" (Medidas de Segurança, S. Paulo, 1937, p. 180). 
venha, atendendo às suas condições pessoais e à defesa social contra o estado perigoso, acaso persistente.

Tem ainda certo arbítrio o juiz nas hipóteses de que cuida o preceito seguinte, art. 84. O concurso de fatos criminosos, que suscitam o reconhecimento da periculosidade, faz com que, às vezes, caibam ao mesmo paciente várias medidas de segurança. Se couberem duas ou mais da mesma espécie, uma só se executará. Se as que couberem forem de espécies diferentes, o juiz imporá uma ou mais dentre elas, tendo em apreço a periculosidade. Não deverá, porem, omitir a que se ajuste à previsão legal sobre a periculosidade presumida. Tais normas serão observadas tanto no momento da imposição das medidas, por sentença judicial, como tambem, mais tarde, quando tenham de ser executadas. O juiz da execução ministrará, de acordo com esses critérios, a orientação unitária aconselhavel, quando impostas as medidas por diferentes magistrados.

9. Por que, nos termos do art. 85 do Código Penal, fugindo o paciente do estabelecimento em que esteja internado, recomeça a fluir, na data do reinício da execução, o prazo mínimo de duração da medida de segurança? A lei excetua, aliás, os internados em manicômio judiciário e em casa de custódia e tratamento.

Aí está um ponto em que, na regulamentação legislativa, as medidas de segurança diferem das penas privativas de liberdade, em relação às quais o tempo vencido não se cancela por efeito da evasão do sentenciado.

Furtando-se à execução da medida, o individuo revelase insubmisso à disciplina, com que se intenta elidir-lhe a periculosidade. $E$ esta se denuncia integra.

Se tal razão pode não ser exata num ou noutro caso, a determinação legal, contudo, vale como advertência, tendente a evitar fugas. Nos estabelecimentos de trabalho, reeducação ou ensino profissional, a vigilância não pode, nem deve, ser rigorosa como num presídio. 
Quanto ao manicômio judiciário e à casa de custodia e tratamento, a fiscalização é necessariamente mais intensa, o que terá levado o legislador a dispensar aquela especial cominação, que para os alienados nem teria sentido.

10. Deixando de analisar um ou outro dispositivo, que não ofereça decisivo interesse para a compreensão do instituto em seus lineamentos, passo ao estudo das medidas de segurança em espécie.

Vejamos quais foram acolhidas em nossa legislação. Dividem-se em medidas de segurança patrimoniais e pessoais. As pessoais são detentivas ou não detentivas. As medidas de segurança patrimoniais são duas, somente: o confisco e a interdição de estabelecimento ou sede de associação ou sociedade.

São as pessoais as mais importantes medidas de segurança. As detentivas são as indicadas no art. $88, \S 1$. $^{\circ}$. Consistem na internação em determinados estabelecimentos: I - manicômio judiciário; II - casa de custódia e tratamento; III - colônia agricola, instituto de trabalho, de reeducação ou de ensino profissional.

As medidas de segurança não detentivas são a liberdade vigiada, o exílio local e a proibição de permanência em determinados lugares.

11. A internação em manicômio judiciário aplica-se aos indivíduos absolvidos por serem absolutamente irresponsaveis. A duração da medida é proporcional ao tempo de duração mínima da pena que caberia ao crime. Um doente mental pode praticar, em consequência da sua enfermidade, um crime de maior ou menor gravidade. A natureza do delito indica o grau, mais ou menos acentuado, da sua periculosidade. Quanto mais grave for o crime, mais propenso o julgador se sentirá a acreditar que o sujeito ativo da infração é perigoso. Um louco que mata parece mais temivel do que um louco que simplesmente furta. Por isso, o tempo mínimo em que deverá ficar o insano mental 
retido no manicômio judiciário, em execução dessa medida de segurança, é correlato à pena mínima prevista, abstratamente, na lei. Se esta, por exemplo, comina, ao crime, pena de reclusão não inferior, no mínimo, a doze anos, o tempo mínimo de permanência no manicômio judiciário é de seis $\operatorname{anos}\left(\operatorname{art} .91, \S 1 .^{\circ}, \mathbf{n}^{\circ} \mathrm{I}\right)$. A lei discrimina as demais hipóteses, sempre estabelecendo proporção entre o tempo mí. nimo da pena do delito e o tempo mínimo para a segregação no manicômio.

Tomando-se por base esse tempo mínimo, faz-se periodicamente exame das condições mentais do delinquente, para se verificar se já está apto a ser restituido à liberdade. Enquanto perdurar a sua periculosidade, ficará no manicô. mio judiciário.

o Código Penal, entretanto, esclarece que, se o entender conveniente o juiz, poderá aplicar ao insano mental absolvido, não essa medida de segurança, mas uma outra, a internação em casa de custódia e tratamento. Essa medida é precipuamente destinada aos indivíduos de imputabilidade restrita a que alude o art. $22, \S$ único, do Código.

Ainda se cogita, na lei, de uma hipótese mais benigna, em que o juiz, em vez de mandar o criminoso irresponsavel para o manicômio, o submeterá tão somente à liberdade vigiada. Isso poderá dar-se, nos termos ido art. 91, § 2. ${ }^{\circ}$, quando o lapso de tempo mínimo de internação no manicômio seria de um ano. A faculdade é concedida em consideração à escassa gravidade das infrações à que corresponde aquele tempo mínimo de internação.

Procurando acautelar a defesa social, estabeleceu o Código (art. 91, $\S 5 .^{\circ}$ ) um período de prova, de um ano, em que o insano mental, que sai do manicômio judiciário, fica submetido a liberdade vigiada. Será reinternado se a enfermidade que parecia debelada se reacender e ele se revelar, de novo, perigoso.

12. Da internação em casa de custódia e tratamento cogita o art. 92. São dois os casos em que é empregada. 
Aplica-se aos indivíduos de imputabilidade restrita, que são condenados atenuadamente, em virtude do que dispõe o artigo 22, § único, do Código Penal. Aplica-se tambem aos indivíduos que venham a delinquir por efeito de embriaguez habitual, produzida pelo alcool ou pelo uso de entorpecentes. A exemplo do que se preceituou quanto à internação eni manicômio judiciário, tambem se traçou aquí, para os indivíduos fronteiriços, proporção entre a pena mínima cominada para cada crime e o tempo mínimo de internação na casa de custódia e tratamento. A internação será, por exemplo, no mínimo de três anos, se se tratar de condenado por crime a que a lei comine pena de reclusão por tempo não inferior, no mínimo, a dez anos.

Quanto aos demais individuos a que se aplica a medida, os embriagados, a duração mínima é, em qualquer hipótese, de seis meses.

Nas infrações de menos importância, em que a internação na casa de custódia e tratamento, tendo em vista a proporção estabelecida, seria de pequena duração (seis meses), a lei permite que o juiz substitua essa medida de segurança pela liberdade vigiada, tal como se dá com relação ao manicômio judic:ário.

A casa de custódia e tratamento é uma prisão-hospital, um estabelecimento destinado a segregar, principalmente, o indivíduo perigoso responsavel, cuja periculosidade resulta de anomalias menta s, que não acarretam a sua total inimputabilidade. $O$ seu regime deve ser predominantemente curativo, pois se destina a delinquentes enfermos, cuja periculosidade terá de ser neutralizada por uma terapêutica tendente a promover-lhes, antes da rehabilitação moral, a rehabilitação fís:ca. Mas esta nem sempre é praticavel. A alta temibilidade, comum entre os anormais de responsabilidade reduzida, indica, sem a necessidade de mais esclarecimentos, a razão de ser da palavra "custódia" na denominação híbrida do instituto em apreço. 
13. De outra medida de segurança detentiva cogita o artigo 93. À escolha do juiz, conforme o caso, poderá ser o indivíduo perigoso internado numa colônia agrícola, num instituto de reeducação, de trabalho ou de ensino profissional.

Quais, porem, serão os indivíduos a que cabe tal internação? O artigo, no seu inciso I, declara que essa medida deve ser aplicada, por dois anos pelo menos, ao condenado por crime doloso, se reincidente. A primeira categoria, portanto, de indivíduos sujeitos à internação é a dos reincidentes. Os ladrões habituais, por exemplo, estão sujeitos a essa complementar privação da liberdade, que pode prolongarse, como já expliquei, por muito mais tempo, indefinidamente.

Tal medida de segurança deve ser aplicada ainda (inciso II), durante um ano, pelo menos, ao condenado a reclusão por mais de cinco anos e ao condenado a pena privativa de liberdade, se o crime se relaciona com a ociosidade, a vadiagem ou a prostituição.

Esse inciso II reclama uma ponderação importante. Pode parecer que, sempre que alguem for condenado a uma pena de reclusão por mais de cinco anos, está sujeito, ipso facto, à medida de segurança detentiva consistente no recolhimento a um dos aludidos estabelecimentos. E' um equivoco. Quem assim concluir, o fará por ler isoladamente esse texto, sem o confrontar com o artigo 76, que firma os pressupostos da aplicação da medida de segurança, os quais são a existência de crime e a periculosidade do agente. Não basta que o indivíduo tenha cometido crime punido com pena de mais de cinco anos de reclusão para estar sujeito à medida de segurança. E' preciso que o juiz faça apreciação positiva da sua periculosidade ou que esta seja presumida, nos casos legais, para aplicar medida de segurança, subsidiariamente.

Se o crime punido com pena privativa de liberdade tiver relação com a ociosidade, a vadiagem ou a prostituição, entende a lei penal ser cabivel medida de segurança. Mas 
só na hipótese de ser perigoso o agente. Uma prostituta pratica um crime numa casa de tolerância. Dir-se-á - e quasi sempre se dirá com acerto - que o fato tem relação com a prostituição. Só por isso, todavia, não será a criminosa submetida a medida de segurança. E' indispensavel tratar-se de mulher perigosa.

Acerca das medidas detentivas esclarece o art. 90 do Código Penal que o internado deve ser submetido a regime de reeducação, de tratamento ou de trabalho, conforme suas condições pessoais; e que o trabalho deve ser remunerado. De grande utilidade como processo ressocializador, o trabalho será, evidentemente, obrigatório, em regra, nos estabelecimentos que se destinem a essas medidas, com exceção do manicômio judiciário. Dispõem, complementarmente, a respeito do assunto, os arts. 764 e 765 do Código de Processo Penal.

14. Medida de segurança destinada, segundo prevê a lei, a larga aplicação, é a liberdade vigiada, objeto do art'. 94 do Código Penal. Tal como acontece com as demais medidas, encontram-se no Código de Processo, em relação a esta, numerosas disposições eșclarecedoras.

Basta atentar nos diversos incisos do art. 94 para se compreender como, na verdade, deve ser difundida a sua aplicação. Ela é obrigatória, como período de prova, em se tratando de enfermo mental restituido à liberdade após a internação em manicômio judiciário. Tambem se aplica àqueles que saem de casa de custódia e tratamento. A lei faz referência, ainda, ao liberado condicional. Transmuda-se na medida de segurança que estudamos o último período da pena privativa de liberdade. 0 egresso das prisões, que obtem o livramento condicional, permanece sob vigilância. E a lei ainda alude a outras hipóteses: ao transgressor da proibição de frequentar determinados lugares e, finalmente (e isso de acordo com o inciso VI do art. 94), é a medida aplicavel quando a lei não especificar outra medida de segurança. Quando couber, em determinada hipótese, me- 
dida de segurança não indicada pela lei, entende-se que é a liberdade vigiada. Caberá medida de segurança sempre que concorrerem os pressupostos do art. 76 do Código Penal: prática de fato previsto como crime e periculosidade do agente.

Considere-se, ademais, o seguinte. Não possuimos todo o aparelhamento necessário à perfeita aplicação do Código Penal. Não foram criados no país os estabelecimentos, de que fala o Código, destinados ao cumprimento das medidas de segurança (14), excet'o, em algumas das unidades federativas, o manicômio judiciário, que preexistia. Por isso mesmo, a Lei de Introdução ao Código Penal, atendendo a essa deficiência, determinou que, enquanto não houver manicômio judiciário, bem como casa de custódia e tratamento, poderá a internação, que deveria fazer-se num desses gêneros de instituição, ser realizada em casa de saude, em manicòmio comum, em asilo, em qualquer estabelecimento, enfim, que possa fazer as vezes de manicômio judiciário, embora imperfeitamente. $\mathrm{E}-\mathrm{o}$ que nos interessa neste instante dispõe que a liberdade vigíada será a medida sucedânea da internação, que se não puder praticar em colônia agricola, instituto de trabalho, de reeducação ou ensino profissional.

Quem executará a medida de segurança consistente na liberdade vigiada? Diz a lei que, na falta de órgão especial, incumbe a execução à autoridade policial. A polícia, pois, enquanto não dispuserem diversamente as leis, deverá executar a liberdade vigiada.

Seria, realmente, preferivel que se constituisse um órgão especial, na organização judiciária, para o desempenho

(14) No Estado de São Paulo o dec.-lei n. 12.924, de 4 de setembro de 1942 , a que se seguiu o regulamento baixado pelo decreto $n$. 13.182, de 12 de janeiro de 1943, criou o Instituto Correcional da Ilha Anchieta, atribuindo-lhe uma secção destinada ao cumprimento da medida de segurança de que trata o art. 88, $\S 1 .^{\circ}$, n. III. do Código Penal (internação em colônia agrícola, ou instituto de trabalho, reeducação ou de ensino profissional). Mas essa secção ainda não entrou a funcionar. 
dessa medida de segurança. E' facil perceber a importância de que ela pode revestir-se no sistema de prevenção dos crimes. Bem executada, por agentes capazes de uma verdadeira atividade filantrópica, de proteção e assistência. junto àquele que foi considerado perigoso, mas que, afinal, foi restituido ao convívio social, poderá a liberdade vigiada produzir ótimos resultados. Confiada, porem, a agentes de polícia, possivelmente incultos e inhabeis, dará resultados nulos, senão contraproducentes. E' bem verdade que o Código de Processo recomenda que essa medida de segurança seja exercida discretamente, de maneira que não prejudique de forma alguma o vigiado. Não basta, entretanto, a platônica advertência legal, para que se supram falhas inevitaveis ante a inexistência de um aparelhamento adequado.

A pessoa submetida à liberdade vigiada terá de respeitar as condições que lhe são impostas, como normas de sua conduta, pelo magistrado, em conformidade com o que extensamente enuncia o art. 767 do Código de Processo Penal. Se inobservar tais condições, sofrerá medida de segurança detentiva. E' o que está expresso no art. 96 do Código Penal: "No caso de transgressão das obrigações resultantes de liberdade vigiada, o juiz pode, ressalvado o disposto no art. 64, parágrafo único (15), determinar a internação, até seis meses, em um dos estabelecimentos referidos no art. 88 , $\S 1 .^{\circ}$, n. $^{\circ}$ II e III". O infrator fica sujeito a permanecer, até seis meses, em um dos estabelecimentos destinados às medidas de segurança detentivas, exceto o manicômio judiciário.

Por aí se aquilata a relevância da fiscalização a ser exercida junto ao vigiado. E' através das informações que são remetidas ao juiz, acerca do procedimento do paciente, que será possivel aferir a oportunidade e a conveniência des-

(15) A ressalva refere-se ao livramento condicional, em que a inobservância das condições impostas acarreta 0 retorno do sentenciado a cárcere, para continuar a cumprir a pena de reclusão ou detenção. 
sa posterior detenção. De acordo com a lei processual, cabe à autoridade policial, incumbida de superintender a vigilância, informar ao juiz, dentro de certo prazo, antes de terminar a v-gência da medida de segurança, sobre se convem, ou não, mantê-la. Será através dos dados consignados no relatório da autoridade policial que o juiz colherá elementos para decidir.

15. Tratemos, agora, das duas restantes medidas de segurança pessoais. Uma é o exílio local, a que se refere o art. 97: “O exílio local consiste na proibição de resid.r ou permanecer o condenado, durante um ano, pelo menos, na localidade, município ou comarca em que o crime foi praticado".

E' facil perceber a utilidade preventiva dessa medida.

Muitas vezes, a permanência do condenado no lugar do crime ou suas proximidades constitue fonte de novas infrações. Por exemplo, alí moram pessoas envolvidas, direta ou indiretamente, no acontecimento delituoso, e cujos interesses ou sentimentos fermentam novos dissídios, ao contacto do responsavel pelo fato passado, produzindo-se choques perturbadores da ordem. E' razão para que se confira ao prudente arbítrio do magistrado a possibilidade de impedir, pela aplicação dessa medida de segurança, que se repitam violações à lei penal.

Imposta a medida, o juiz comunicará a sua decisão à autoridade policial do lugar ou dos lugares onde o exilado está proibido de permanecer ou residir (art. 771 do Código de Processo Penal). Se desatender à proibição, o infrator será conduzido à presença do juiz, que poderá mantê-lo detido até proferir decisão. Reconhecida a transgressão, ficará o paciente sujeito à liberdade vigiada, com a indispensavel fixação de lugar onde deverá residir.

Finalmente, o art. 98 refere-se à proibição, imposta ao condenado, de frequentar determinados lugares. Se se trata de crime cometido sob a ação do alcool, essa proibição é de um ano, no mínimo, e, nos demais casos, será no mínimo 
por três meses. Cabe tambem à autoridade policial fiscalizar o cumprimento dessa medida de segurança (art. 772 do Código de Processo Penal), comunicando ao juiz qualquer eventual transgressão.

16. Entre as medidas de segurança de carater paírimonial figura a interdição de estabelecimento ou sede de sociedade ou associação (art. 99) .

Perante a nossa lei, ninguem o ignora, não é admissivel a responsabilidade criminal das pessoas jurídicas. A responsabilidade penal continua exclusivamente individual. Se não se pode impor pena a uma coletividade, a uma sociedade, a uma associação, sofrerão a providência repressiva os indivíduos, cada um de per sí, aos quais se possa atribuir a causalidade material e psíquica do acontecimento vedado pela lei penal. Não se esqueça, porem, que uma poderosa providência preventiva cabe contra as pessoas jurídicas de direito privado. E' a consistente na interdição de estabelecimento ou sede de associação ou sociedade. Impõe-na o juiz criminal, se o estabelecimento, sociedade ou associação serve de meio para a prática de infração penal.

Durante o tempo de execução da medida, que não durará menos de quinze dias nem mais de seis meses (16), não poderá a sociedade ou associação exercer a sua atividade, nem no local interditado, nem em outro. Interditado, nas mesmas condições, tambem pode ser um estabelecimento comercial ou industrial, pertencente a sociedade comercial ou a comerciante com firma individual. A medida de segurança vedará, então, o exercício das atividades comerciais ou industriais, no local, ao condenado ou a terceiro a quem ele tenha transferido o seu comércio ou indústria. Não se trat'a, pois, de medida de segurança cabivel exclusivamente a pessoas jurídicas.

(16) E' de notar-se que a duração indeterminada das medidas de segurança, decorrente do art. 81 do Código Penal, diz respeito tão só às medidas de carater pesisoal. Não se estende às de carater patrimonial. 
O Código de Processo Civil apresenta uma providência ainda mais radical, no gênero. $\mathrm{O}$ seu art. 670 preceitua: “A sociedade civil com personalidade jurídica, que promover atividade ilícita ou imoral, será dissolvida por ação direta, mediante denúncia de qualquer do povo, ou do órgão do Ministério Público". Adverte, de igual modo, o dec.-lei n.. 2.627, de 1940, em seu art. 167: "Será judicialmente dissolvida, a requerimento do órgão do Ministério Público, a sociedade anônima ou companhia, ou a sociedade em comandita por ações, que tiver objeto ou fim ilícito, ou desenvolver atividade ilícita ou proibida por lei".

17. O confisco não é, como o nome poderia sugerí-lo, nada parecido com a antiga pena de confiscação dos bens, tão odiosamente utilizada. Dispõe o art. 100 do Código Penal: "O juiz, embora não apurada a autoria, deve ordenar o confisco dos instrumentos e produtos do crime, desde que consistam em coisa cujo fabrico, alienação, uso, porte ou detenção constitue fato ilícito". Se a autoria é descoberta e sobrevem a condenação do culpado, perde ele os instrumentos ou produtos do crime, como efeito da sentença condenatória (art'. 74, n. ${ }^{\circ}$ II) . Mas na hipótese do art. 100 a condenação não é possivel, porque não se consegue individuar a responsabilidade pelo delito. Isso não impede, todavia, a apreensão daquelas coisas nas circunstâncias mencionadas em tal dispositivo, a título preventivo, ou seja como medida de segurança.

O confisco poderá ser ordenado não só na sentença $a b-$ solutória, como tambem no despacho de arquivamento do inquérito ou na sentença de impronúncia (art'. 779 do Código de Processo Penal).

18. O art. 101 do Código Penal declara: “A imposição de medida de segurança não impede a expulsão de estrangeiro". Se, em virtude das leis reguladoras da situação dos estrangeiros no território nacional, estiver um deles na contin- 
gência de ser expulso do nosso país, a expulsão não será obstada ou retardada pela circunstância de lhe ser aplicavel mo dida de segurança. Mesmo que alguma lhe tenha sido imposta, não será executada com prejuizo da expulsão. Deverá o estrangeiro, na hipótese de cometer uma infração, cumprir a respectiva pena. Dela não o isenta a conveniência de expulsá-lo. Cumprida a sanção penal, o condenado pode, sem mais demora, ser expulso.

De acordo com as leis que regulam a expulsão de estrangeiros, acarreta-a a condenação por determinados delitos e contravenções, incluidos em numeroso ról, a que nem falta menção extensiva a todos os crimes inafiançaveis. Acarreta-a, desde que o estrangeiro não conte mais de 25 anos de residência legítima no país, ou não tenha filhos brasileiros, oriundos de núpcias legítimas, sendo tambem condição que o estrangeiro não haja manifestado pensamentos ou praticado atos que importem menosprezo ao Brasil ou suas instituições (dec.-lei $\mathbf{n}^{\circ} 1.377$, de 27 de junho de 1939 , combinado com o dec.-lei n..$^{\circ} 479$, de 8 de junho de 1938). E o art. 10 do dec.-lei $n .^{\circ} 479$ estipula que a expulsão se dará depois de cumprida a pena.

Compreende-se a razão do art'. 101 do Código. A expulsão vale como medida de segurança, no sentido de que previne a prática de novos crimes, pelo mesmo delinquente, no território brasileiro. Há códigos, como o italiano, que inserem essa providência na lista das medidas de segurança. Sem chegar a tal solução técnica, o nosso estatuto deixou nítido, porem, que a expulsão substitue eficazmente a execução das medidas de segurança cabiveis ao estrangeiro que haja delinquido.

Analogamente, o Código Penal suiço de 1937, que entrou em vigor em 1941, dispôs, no art. 42, que, se o condenado for estrangeiro, o juiz poderá, ao invés de fazê-lo internar em instituto de medida de segurança, impor-lhe a expulsão do território nacional, após o cumprimento da pena privativa de liberdade. 
19. O instituto das medidas de segurança tambem complementa, no desempenho da sua função profilática, o combate ao perigo, imanente nas contravenções. Na lei que disciplina essas infrações, todas as medidas de segurança do Código Penal são aproveitadas, exceto uma, o exílio local. Com o exílio local se evita que o autor de um crime permaneça no lugar do fato, ocasionando, com a sua presença, desassocego, germe de outros delitos. Tal receio não é admissivel nas modestas ocorrências que constituem o conteúdo das contravenções.

A Lei das Contravenções, no art. 14, reporta-se a algumas das hipóteses de periculosidade presumida indicadas no Código Penal. E introduz uma, específica do assunto de que se ocupa: presume-se perigoso o indivíduo condenado por vadiagem ou mendicância. Os vadios, que sejam realmente sistemáticos inimigos das ocupações lícitas, e os mendigos, que esmolam por espírito de ociosidade ou cupidez, são, com efeito, indivíduos cujo teor de existência é propício à pratica de delitos. Representam, segundo uma expressão muito em voga entre os escritores de língua castelhana e italiana, elementos "malviventes". E, por isso mesmo, são perigosos.

Quanto à reincidência em contravenção, todavia, a Lei das Contravenções só a considera como índice especial e indubitavel de periculosidade a propósito de determinadas infrações: a do art. 50 (exploração de jogos de azar) e a do art. 58 (jogo do bicho).

A medida de segurança aplicavel aos vadios ou mendigos e aos reincidentes na exploração do jogo do bicho é a internação em colônia agrícola, ou em instituto de trabalho, de reeducação ou de ensino profissional.

20. Não encerremos a explanação da matéria sem deduzir, em sintese, as peculiaridades com que foram introduzidas no direito positivo brasileiro as medidas de segu- 
rança, como providências preventivas que se procurou diferençar das penas, providências repressivas.

A) A imposição de pena não depende de que seja perigoso o autor da infração. Sem a periculosidade, ainda que presumida, do paciente, nunca se dará aplicação de medida de segurança.

B) Ao contrário do que ocorre com as penas, a aplicação das medidas de segurança pode ser suscitada por fato criminoso anterior ao preceito legal.

C) Ao inverso das penas, as medidas de segurança mais importantes, as pessoais, sejam detentivas ou não detentivas, têm duração indeterminada.

D) A indicação do tempo de uma pena, na sentença, representa o máximo da sua duração, naquele caso. $A$ indicação do tempo de vigência da medida de segurança pessoal, na decisão judicial, traduz a sua duração mínima.

E) Contrariamente ao que se verifica no cumprimento das penas privativas de liberdade, num dos tipos de medidas de segurança detentivas a evasão do internado ocasiona o reinício da execução sem desconto do tempo vencido.

F) A aplicação de pena supõe que tenha sido cometido um crime. Tambem o supõe a aplicação de medida de segurança, mas com exceções.

G) Jamais se dá imposição de pena sem o pressuposto da responsabilidade. Cabem medidas de segurança aos irresponsaveis.

H) Em consequência, - convem salientar - as medida de segurança, ao contrário das penas, podem ser impostas em sentença absolutória.

I) Relativamente à aplicação das penas, o poder jurisdicional esgota-se na sentença condenatória. As medidas de segurança ainda são aplicaveis depois de passar em julgado a sentença penal. 
Em conferência proferida, em outubro de 1944, na Faculdade de Direito de Porto Alegre (17), Nelson Hungria, reconhecendo que continuamos ainda muito longe de converter os textos legais sobre medidas de segurança em realidade, alvitra que, por meio de uma flexivel regulamentação, se aperfeiçoe a sua diversificação das penas. Ao passo que na Itália, antes de entrar em vigor o Código Rocco, já tinha sido baixado o "Regulamento per gli istituti di prevenzione e di pena", que orientaria a atividade não só dos estabelecimentos carcerários como dos destinados às medidas de segurança, no Brasil, nesse particular, ainda nada se fez, no terreno prático, desale que surgiu o Código Penal de 1940.

As medidas de segurança, para bem se ajustarem à sua finalidade, necessitam, diz, despir-se do carater aflitivo, o que se poderá conseguir com variadas atenuações do rigor que lhes possa ser inerente. Declara: "Os internados que se mostrarem sensiveis aos processos de cura, especial tratamento ou reeducação, deverão ser favorecidos não só por um sistema de licenças periódicas, sob discreta vigilância (como no regulamento italiano), senão tambem por um regime de semi-libertação, como seja, por exemplo, o de permanência diurna no estabelecimento e pernoite em casa. Em casos especiais, seria mesmo aconselhavel, para os que obtivessem emprego certo, o trabalho fora do estabelecimento e a volta a este para o pernoite. Somente quanto aos enfermos mentais incuraveis seria incondicionalmente ininterrupta a segregação.

"Afora o estritamente indispensavel para a boa ordem interna - prossegue - deve ser excluido o rigor da disciplina. Nada de regimentos detalhados e profusos, como na penitenciária: O trabalho não deve ser imposto como um castigo, conforme acontece, prevalentemente, na execução da pena; mas suasoriamente, reclamado como um saudavel re-

(17) Nelson Hungria, Pena e medida de segurança, no Arquivo Judiciário, 1944, vol. 72, sup., p. 67, e na Revista Forense, 1944, vol. 100, p. 419. 
gime de vida e deixado à escolha do internado, desde que tenha carater educativo ou curativo".

Não titubeia em aconselhar que se rompa "com escrúpulos puritanos em torno à vida sexual dos internados", acenando, assim, corajosamente, para a solução, no tocante às medidas de segurança, de um problema que tem parecido insoluvel quanto às penas privativas de liberdade.

Mas poderá, em verdade, essa esfinge da ciência penitenciária encontrar decifração condigna, ainda que no quadro mais restrito das medidas de segurança?

Essas e outras propostas, inspiradas em louvaveis intuitos, condicionam-se, em parte, ao advento de novos textos legais, pois algumas importam em realizações bastante avançadas perante as normas e o espírito dos estatutos vigentes, o penal e o processual penal.

Concordo com o conceituado penalista em que devamos adotar como modelo, na diferenciação procurada, o citado regulamento italiano, em cuja análise Carnevale achou possivel concluir: "As várias disposições regulamentares, na execução da medida de segurança, formam um ambiente que, bem considerado, não pode confundir-se com o outro, em que atua a pena" (18).

Nas linhas de apresentação daquele Regulamento, frisou o ministro Rocco que a diversificação entre as penas e as medidas de segurança teria de refletir-se na organização dos respectivos institutos. Substanciais diferenças de regime foram acolhidas, assim como outras meramente formais, mas nem por isso irrelevantes, como a de se chamar pelo seu nome, não mais por um número, o internado, proscritas na med'da de segurança as palavras sentenciado, réu, presidiário (19).

(18) Emanuele Carnevale, Pene e misure di sicurezza-differenze nell'esecuzione, na Rivista di Diritto Penitenziario, 1935 p. 838.

(19) Em nosiso direito positivo, emprega-se tambem a designação exata: o internado, o internando (arts. 762,763 e 764 do Código de Processo Penal). 
Provavelmente, nenhuma das concessões daquele Regulamento é tão expressiva e valiosa como a das licenças, a título de prêmio: até trinta dias, uma vez por ano, alem de outra, extraordinária, no limite de quinze dias, em casos de grave necessidade do internado, relativa à sua pessoa ou à família.

No Congresso Penal e Penitenciário Internacional realizado em Berlim, em 1935, o problema foi focalizado através da dupla proposição seguinte: "Como deve a execução da pena privativa de liberdade diferençar-se da execução das medidas de segurança que comportam privação de liberdade? - Deve o sistema progressivo ser tomado em consideração tambem para as medidas de segurança?". Foi das mais interessantes, no estudo do assunto, a contribuição de LÉON BELYM, o preclaro inspetor geral honorário dos estabelecimentos penitenciários da Bélgica (20).

Se algum dia os métodos curativos e assistenciais lograrem empolgar o instituto das medidas de segurança, conseguir-se-á, enfim, convencer de que elas representam, na efetividade do seu modo de agir, algo diferente das penas. Mas os penitenciaristas de largo tirocínio nem sempre ousam esperar que tal suceda. Hartvig Nissen (21), presidente da Associação das Sociedades de Patronato da Noruega, pondo em relevo os tropeços que a diferenciação defronta, recorda um ponto que aos teoristas costuma passar despercebido, - que os indivíduos internados por causa do seu perigo constituem uma elite negativa de endurecidos delinquentes, cuja índole é incompativel com um sistema de total suavidade. Exige-se, para com eles, firme disciplina. Eis por-

(20) LÉON BELYM, Des bases d'organisation de l'internement par mesure de surité, des delinquants mentalement normaux, em L'Écrou, 1936, p. 147.

(21) Hartvig Nissen, L'internement est-il un traitement qui se déférencie essentiellement de la peine? - Peine relativement indéterminée et internement", na Revue de Droit Pénal et de Criminologie, 1938, p. 1.223. 
que aquiesce a esta desiludida equiparação: "na realidade, o internamento é a mesma coisa que a pena privativa de liberdade". Assim tambem pensa o criminalista holandês RöLING: é ilusório supor que exista diferença essencial entre a execução da pena privativa de liberdade bem organizada e a execução do internamento bem organizado.

A adoção da pena relativamente indeterminada - indeterminada em seu limite máximo - dispensaria, como sustenta o citado Nissen, o artificioso recurso a providências defensivas pretensamente diversas das penas, mas, afinal, tão parecidas com elas. Assiste-lhe toda razão. E, mais cedo ou mais tarde, há de vir a unificação dos meios de combate ao crime, como uma das conquistas da ciência penal, que, por isso que é ciência, não se pode alicerçar na areia movediça de distinções precárias, em que a verdade é ocultada pelo preconceito e pelas convenções. 